\title{
BIOLOGY
}

\section{Histological remarks of the oviduct and the oviducal gland of Sympterygia acuta Garman, 1877}

\author{
Galindez, EJ.* and Estecondo, S. \\ Cátedra de Histologia Animal, Departamento de Biologia, Bioquímica e Farmácia, \\ Universidade Nacional do Sul, San Juan, 670, 8000, Bahía Blanca, Argentina \\ *e-mail: galíndez@criba.edu.ar \\ Received February 9, 2006 - Accepted September 26, 2006 - Distributed May 31, 2008
}

(With 12 figures)

\begin{abstract}
The elasmobranchs constitute an important resource in Argentinian fishing and they show reproductive characteristics that make them susceptible to the pressure of fishing. In spite of the importance of the resource our knowledge about the species of the Southwestern Atlantic is scarce. In this work we study the microanatomy of the oviduct and the oviducal gland of Sympterygia acuta. The results show a very folded oviduct with mucous and ciliated cells. The oviducal gland depicts the same zonation as other batoids, showing the typical four regions (club, papillary, baffle and terminal). The epithelium lining the glandular lumen is simple columnar with ciliated and glandular cells. The four zones show simple or ramified tubular gland the secretions of which constitute the egg's envelopes. The club and baffle zones are similar to those present in other species. The papillary one depicts a different pattern of secretions that other Rajiformes and the last zone of the gland is characterized by mixed adenomers. The information here exposed constitutes the first report on the microanatomy of the genital tract of S. acuta.
\end{abstract}

Keywords: Elasmobrachs, oviducalgland, reproduction, Sympterygia acuta.

\section{Observações histológicas do oviduto e da glândula oviducal de Sympterygia acuta Garman, 1877}

\begin{abstract}
Resumo
Os elasmobranchii constituem um importante recurso pesqueiro na Argentina e mostram características reprodutivas que os fazem suscetíveis à pressão de pesca. Apesar da importância do recurso, nosso conhecimento sobre as espécies do Atlântico do Sudoeste é escasso. Neste trabalho, estudamos a microanatomia do oviduto e da glândula oviducal de Sympterygia acuta. Os resultados mostram um oviduto muito dobrado, com células mucosas e células ciliadas. A glândula oviducal apresenta as mesmas zonas que outros batóideos, mostrando as quatro regiões típicas (club, papillary, baffle e terminal). O epitélio que reveste o lúmen glandular é simples, com células ciliadas e células glandulares. As quatro zonas mostram glândulas tubulares simples ou ramificadas e suas secreções constituem os envelopes do ovo. As zonas do $c l u b$ e baffle são semelhantes aquelas presentes em outras espécies. A papilar tem um padrão de secreção diferente de outros Rajiformes e a última zona da glândula é caracterizada por adenômeros mistos. A informação aqui exposta constitui o primeiro relato sobre a microanatomia do trato genital de $S$. acuta.
\end{abstract}

Palavras-chave: Elasmobranchii, glândula oviducal, reprodução, Sympterygia acuta.

\section{Introduction}

The southwestern sector of the Atlantic Ocean, between $34^{\circ}$ and $55^{\circ} \mathrm{S}$, plays an important role in the life cycle of several cartilaginous fishes. Birth, growth until sexual maturity, mating and the laying of eggs or breeding, are completed in these coasts (Cousseau, 1986; Chiaramonte, 1998; Lucifora et al., 2000a, 2000b; Chiaramonte and Pettovello, 2000; Braccini and Chiaramonte, 2002; Lucifora et al., 2002). Likewise, the biggest disembarked volumes of chondrichthians come from this region (Massa et al., 2003). In the Southwester Atlantic these species are being exploited at a level that exceeds its level of recovery (Chiaramonte, 1998; Massa et al., 2003; 2004) which not only endangers the population's subsistence but also the balance of the coastal species as a whole (Dulvy and Reynolds, 2002) Cartilaginous fishes come from the Silurian period without major changes. This success is due, in part, to many reproductive particularities, such as internal fertilization and a scarce but well developed number of embryo production, in the oviparity model as well as in the viviparity one (Hamlett, 2005). In spite of these strategies, the group is characterized by slow growth and extensive 
period of gestation (Hoenig and Gruber, 1990) resulting in a low reproductive potential. In the entire group the ovaries produce large oocytes with considerable yolk supplies. As the fertilized egg passes down the oviduct it is encapsulated by secretions produced by the oviducal gland, which is a specialized region of the oviduct which transfers eggs to the uterus, produces egg jelly, forms the tertiary egg envelopes and stores sperm (Hamlett et al., 1998a; Hamlett and Koob, 1999). The gross morphology of the oviducal gland varies between species, but in general consists of two similar dorsoventral flattened halves surrounded by connective tissue (Knight et al., 1996) and their size changes with the reproductive cycle stage. It can be divided into four different morphological zones based on the appearance of the lamellae in longitudinal view. From cranial to caudal, these regions are the club, papillary, baffle and terminal zones and they show different affinity for dyes according to their different functions (Hamlett et al., 1998a).

In spite of the importance of chondrichthians from the evolutive point of view or for their growing importance in commercial fishing (Massa et al., 2003; Cedrola et al., 2005), most investigations in the structure of the genital tract were performed in species arising from intensive fishing zones or special locations (Metten, 1939) (Scyliorhynus canicula); Prasad, 1945 (several species from the Indic Ocean) Pratt, 1993 (several species from the North Atlantic); Knight et al., 1996 (S. canicula); Hamlett et al., 1998a (several species) and 2002 (Iago omanensis) and Smith et al., 2004 (Callorhynchus milii). On the genus Sympterygia, there have been very few investigations (Mabragaña et al., 2002; Oddone and Vooren, 2003) mainly focused on biological features.

The Bahía Blanca estuary is known for its use by fishes for mating, giving birth and as a breeding ground (López Cazorla, 1987; Mabragaña et al., 2002). Two species of genus Sympterygia are present throughout the year, and mature males and females of $S$. acuta show an abundance peck from the middle spring to summer in concordance with data coming from the Argentinean Platform (Mabragaña et al., 2002). Their importance as an economic resource for our fishing is clear (Massa et al., 2003) and the knowledge of their reproductive cycle and particularities will be extremely significant for the management of the stocks.

In this work we analyze the microanatomy and some histochemical characteristics of the oviduct and the oviducal gland of $S$. acuta (bignose fanskate) in an attempt to contribute to knowledge of reproductive characteristics in this local important resource considered as vulnerable (A2bd) from April of 2004 (IUCN, 2004).

\section{Material and Methods}

Eight specimens of $S$. acuta were obtained by line fishing in the internal zone of the Bahía Blanca estuary $\left(38^{\circ} 45^{\prime}-39^{\circ} 45^{\prime} \mathrm{S}\right.$ and $61^{\circ} 30^{\prime}-62^{\circ} 30^{\prime} \mathrm{W}$ ) in November 2003, June, August, September and October of 2004 and April of 2005. In each capture, the depth was no more than $10 \mathrm{~m}$ and the superficial temperature oscillated between $\left(6.9\right.$ to $\left.23^{\circ} \mathrm{C}\right)$. The animals, ranging between 49 to $55 \mathrm{~cm}$ of total length were sacrificed by a blunt trauma to the cranium immediately after having been taken out of the water. On board, the dissection of the reproductive system was carried out and the genital tract was isolated. The oviducal gland was sagitally cut and their pieces, as well as the oviduct, were fixed in formalin or Bouin's fixative, both in sea water. The material was embedded in paraffin $\left(56-58{ }^{\circ} \mathrm{C}\right)$, cut at 5-7 $\mu \mathrm{m}$ thickness and stained with hematoxylin-eosin, Masson's trichromic stain, the periodic acid Schiff technique and the alcian blue technique at 2.5 and $1.0 \mathrm{pH}$ level.

\section{Results}

\subsection{Oviduct (OV)}

The oviduct is a tube-shaped organ that extends from the ostium to the oviducal gland. It is characterized by longitudinal folds (Figure 1). The lining epithelium is simple and columnar, ciliated with glandular cells. Surface cells have the apical cytoplasm with plenty of droplets PAS and $\mathrm{AB}(+)$. On the other hand, cells located in the bottom of the folders have the supranuclear cytoplasm occupied by vesicles $\mathrm{AB}(+)$ and PAS $(+)$ and the perinuclear cytoplasm shows small vesicles strongly PAS (+) (Figure 2). In each longitudinal fold there is a venule immersed in a loose connective tissue. The submucous is thin as well as the muscular longitudinal layer.

\subsection{Oviducal gland $(O G)$}

In general, views the OG of $S$. acuta show four zones (Figure 3 ) characterized by different histological features and affinity to dyes.

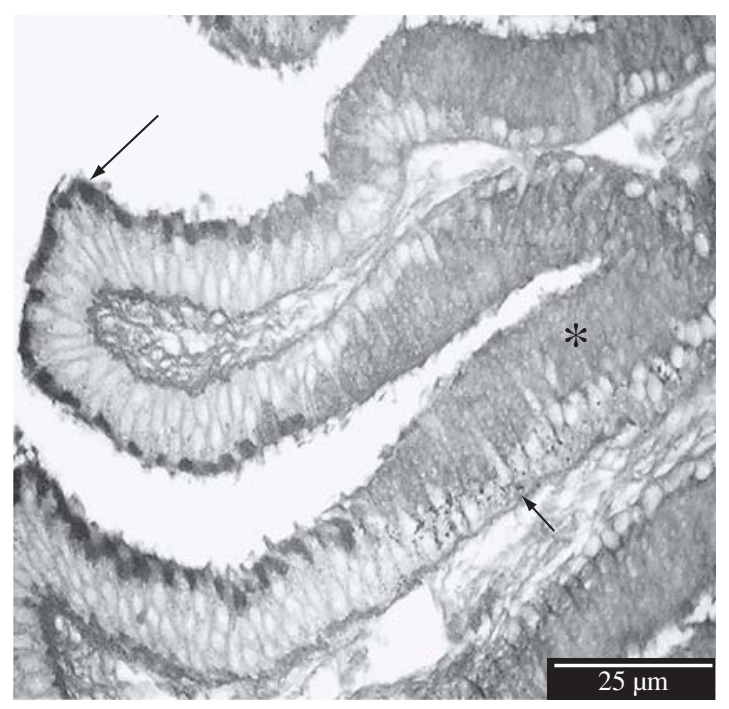

Figure 1. Oviducal folders. Arrow indicates the apical secretion of the surface epithelium; the arrow head shows the adenomer and asterisk depicts the glandular secretion. PAS reaction. Bar $=25 \mu \mathrm{m}$. 


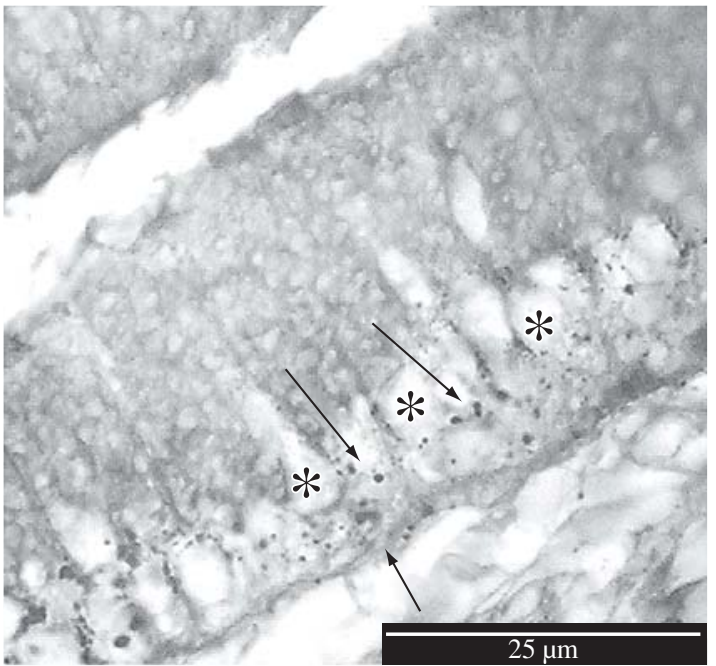

Figure 2. Gland of the oviduct. Asterisks indicate the colorless nuclei; arrow shows the infranuclear small granules and arrowhead shows the basal membrane. PAS $-\mathrm{AB}$ reaction. $\mathrm{Bar}=25 \mu \mathrm{m}$

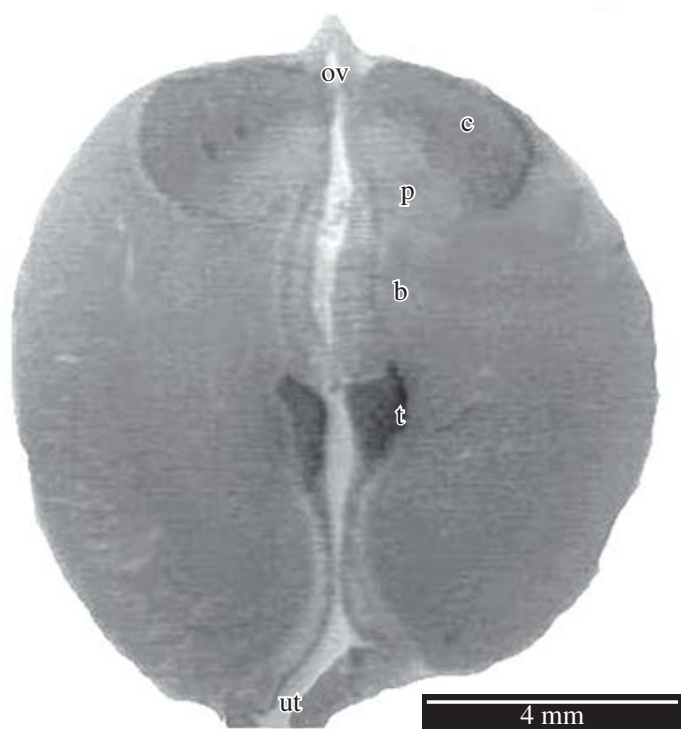

Figure 3. Low magnification of the oviducal gland. c: "club" zone; p: "papillary" zone; b: "baffle" zone and t: "terminal" zone. $\mathrm{PAS}-\mathrm{AB}$ reaction. $\mathrm{Bar}=4 \mathrm{~mm}$.

- Club zone: In the sagittal section it presents 6 to 8 basally truncated and luminal expanded shorter lamellae $(60-80 \mu \mathrm{m})$. The lining epithelium is simple columnar ciliated with a central-basal euchromatic nucleus and sparse mucous cells alternate with them (Figure 4). Tubular glands open between lamellae and present ciliated cells with a euchromatic nucleus and the cytoplasm has plenty of big vesicles (Figure 5). The PAS and $\mathrm{AB}$ techniques (Table 1) indicate the presence of muccopolysaccharides. Connective tissue is

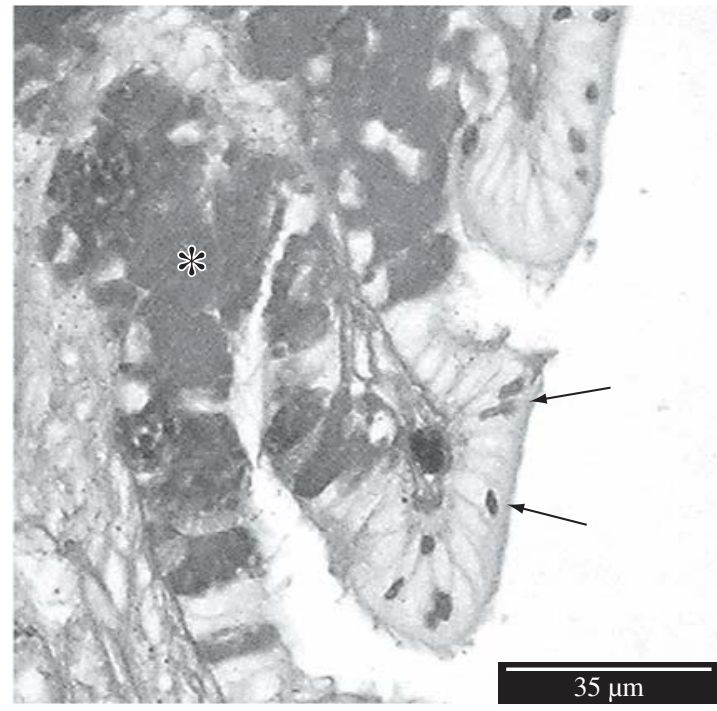

Figure 4. Small plates of the "club" zone. Arrows indicate the glandular cells. PAS reaction. Bar $=35 \mu \mathrm{m}$.

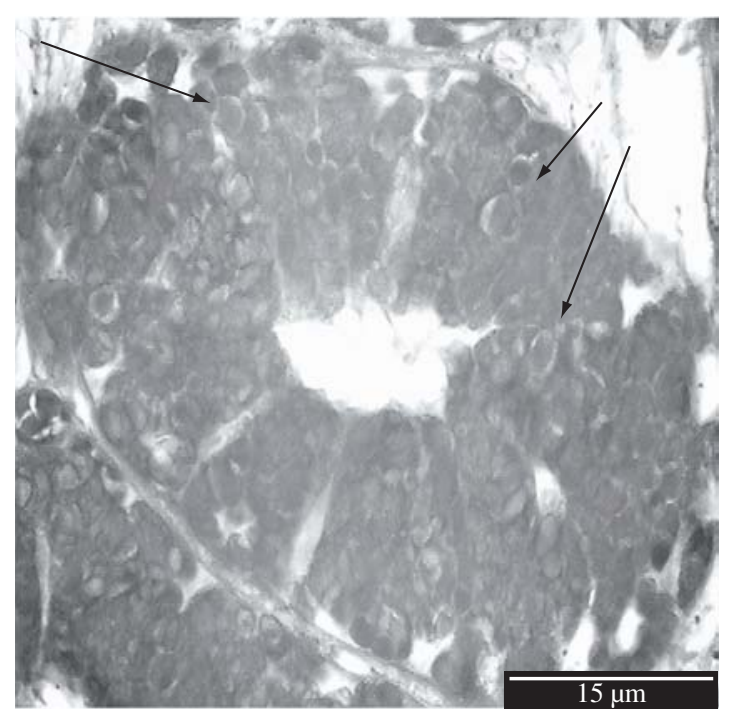

Figure 5. Adenomer of the "club" zone. Arrows indicate the cytoplasmic granules, some of them with a halo surrounding the core. Masson stain. Bar $=15 \mu \mathrm{m}$.

restricted to the space between the adenomeres and the longitudinal muscular layer is minimal;

- Papillary zone: This region shows $12-14$ papillaeshaped lamellae $(80-100 \mu \mathrm{m})$ in the sagittal section. The lining epithelium is simple columnar ciliated (Figure 6) with glandular cells more abundant than in the club zone. Tubular glands are simple or occasionally ramified (Figure 6). Cranial adenomers include cells with big granules PAS (+) with a dense core, or a mixture of cells PAS (+)/AB (+), and caudal adenomers, cells AB $(+)$ only (Figure 7a,b, Table 1). Connective tissue 
Table 1. Muccopolysaccharides reactivity of the oviductal gland.

\begin{tabular}{lllll}
\hline Zone & \multicolumn{1}{c}{ PAS } & AB 2.5 & \multicolumn{1}{c}{ AB 1.0 } & \multicolumn{1}{c}{ PAS/AB 2.5 } \\
\hline Club & +++ & ++ & + & Violet \\
Papillary & $+++(\mathrm{cr})$ & $-(\mathrm{cr})$ & $-(\mathrm{cr})$ & Red (cr) \\
& $+(\mathrm{ca}, \mathrm{fc})$ & $++(\mathrm{ca}, \mathrm{fc})$ & $+(\mathrm{ca}, \mathrm{fc})$ & Blue and Red (ca, dc) \\
Baffle & - & - & - & - \\
Terminal & $+(\mathrm{ma})$ & $+++(\mathrm{ma})$ & $+(\mathrm{ma})$ & Blue (ma) \\
& $-(\mathrm{sa})$ & $-(\mathrm{sa})$ & $-(\mathrm{sa})$ & \\
\hline
\end{tabular}

ma: mucous acini, sa: serous acini, cr: cranial, ca: caudal, fc: few cells, different cells.

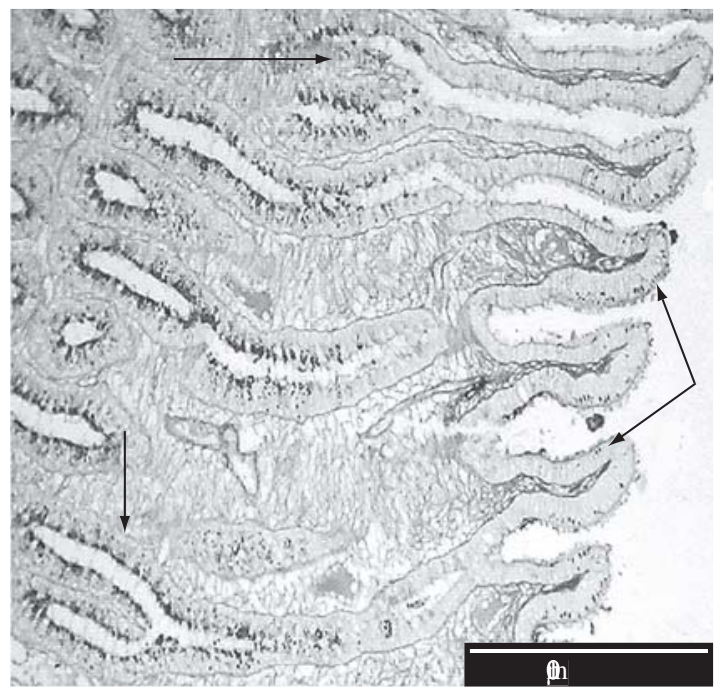

Figure 6. General view of the "papillary" zone. Arrows indicate the luminal epithelium, arrowheads show the ramified glands. PAS reaction. $\mathrm{Bar}=100 \mu \mathrm{m}$.

is quite cellular, but less plentiful and vascularized than that of the club zone and the muscular layer is similar to the previous zone;

- Baffle zone: Consists of 30-35 apical expanded lamellae $(300-400 \mu \mathrm{m})$ that alternate with transverse grooves. The glandular duct ends in a pair of spinnerets, then passing to the transverse grooves (Figure 8). The lining epithelium of the lamellae is simple ciliated columnar with oval and basal nucleus and some mucous cells more abundant in the lateral surface. In the spinnerets the epithelium is cuboidal with a central nucleus and without a glandular cell (Figure 9). Tubular glands have cells with round cytoplasmic granules, basal nucleus and evident nucleolus. As we look to the end of adenomers, their diameter increases progressively due to the increase of secretion. PAS and $\mathrm{AB}$ stains are negative (Table 1). In secreting females it is possible to see the formation of proteinic ribbons inside the adenomers (Figure 10); and

- Terminal zone: Is not organized in lamellae (Figure 11). The lining epithelium is columnar

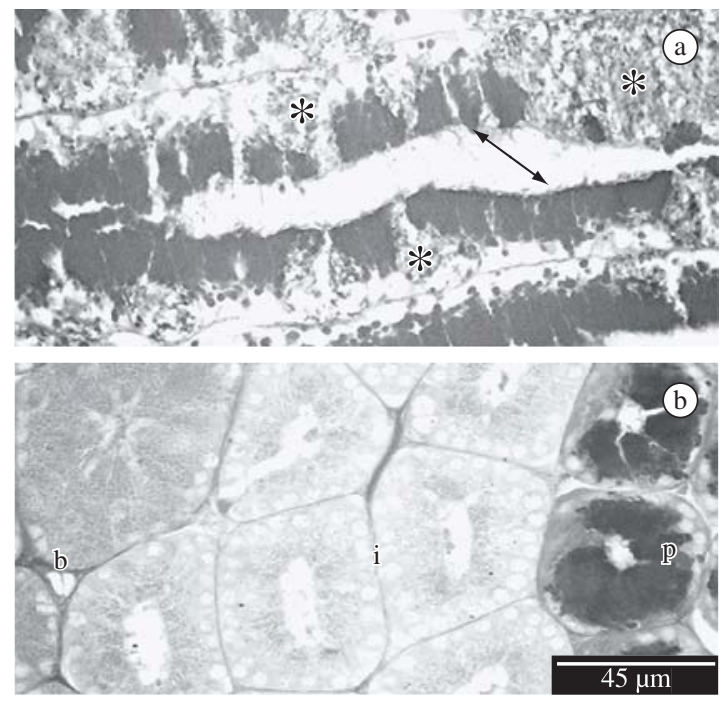

Figure 7. a) Longitudinal view of most distal zone (intermediate) of the "papillary" zone. Double arrow indicates the PAS positive cells and asterisks the AB positive cells; and b) Transversal view of the same zone, b: "papillary" cranial zone; i: intermediate "papillary" zone and b: "baffle" zone. a, b) PAS $-\mathrm{AB}$ reaction. $\mathrm{Bar}=45 \mu \mathrm{m}$.

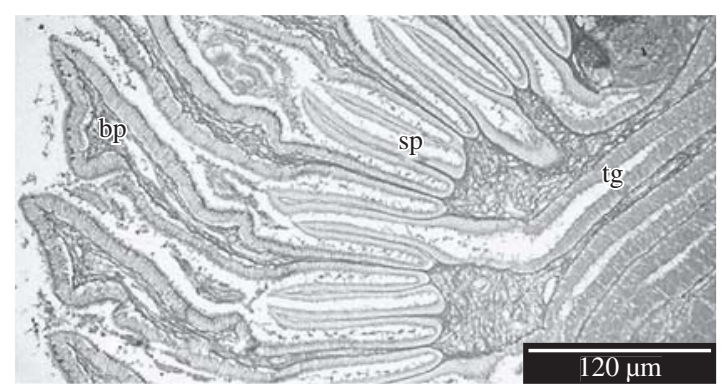

Figure 8. Low magnification of the "baffle" zone. tg: tubular gland; sp: spinnerets; bp: baffle plates. Masson stain. Bar $=120 \mu \mathrm{m}$.

simple ciliated. The most luminal tubular glands are mucous, with ciliated cells, meanwhile glands of the bottom are a mixture of serous, with small granules, and mucous, with large vesicles cells 
(Figure 12). Finally the glands closest to the muscular layer are clearly serous. Results for the $\mathrm{AB}$ and PAS reaction are in Table 1 . In serous acini it is possible to see, with high magnification, that ciliated cells organize the secretion to form a filiform structure and the presence of a hialinized ring surrounding the core is clear (Figure 12).

\section{Discussion}

The elasmobranchs constitute an important resource in Argentinian fishing (Massa et al., 2004) and skates are the elasmobranch group most vulnerable to fishing pressure (Dulvy and Reynolds, 2002). They are a highly diversified group which shows a high morphological conservatism (McEachran and Dunn, 1998). They are oviparous animals that produce large eggs enclosed in a capsule deposited in shallow waters. The oviparity model of skates is probably an adaptation to maximize fecundity (Lucifora and García, 2004). In oviparous fish-

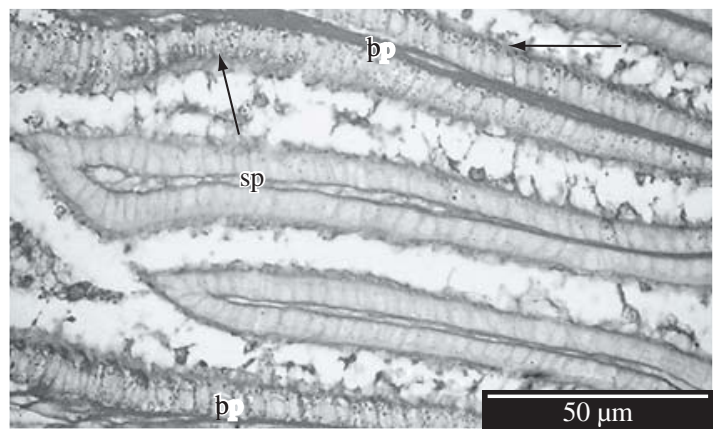

Figure 9. More magnification of the "baffle" zone. sp: spinnerets, bp: baffle plates, arrows indicate the glandular epithelium of the plates. PAS reaction. Bar $=50 \mu \mathrm{m}$.

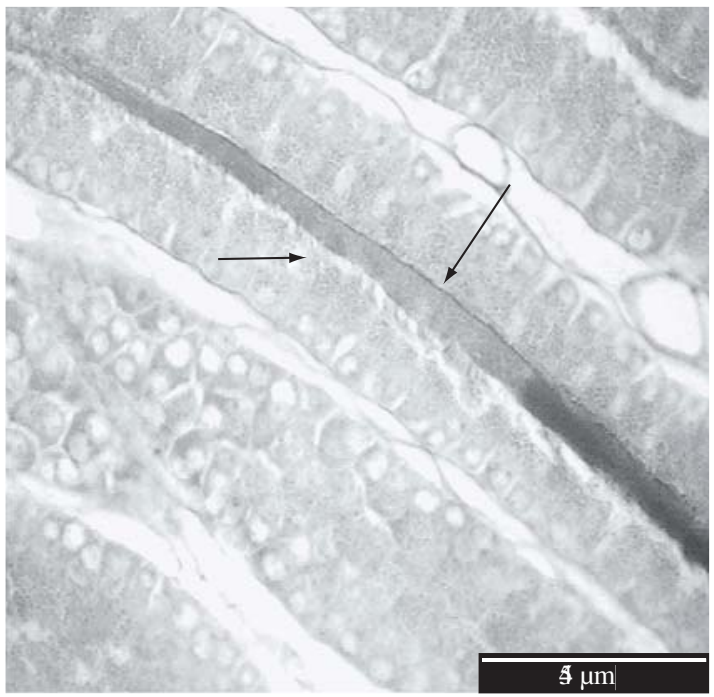

Figure 10. Tubular glands of the "baffle" zone. Arrow indicates the ribbon-like secretion and arrowhead shows the cilia. $\mathrm{AB}$ reaction. $\mathrm{Bar}=45 \mu \mathrm{m}$. es the oviducal gland produces not only the jellies that envelop the egg, but also the capsule with their ornamentation (Hamlett et al., 1998a). This structure has the same basic organization in all studied elasmobranchs but the relevance of each glandular region is correlated with the reproductive adaptations of the species (Hamlett, 2005). S. acuta shows all the four zones in which the gland was subdivided according to their morphology and tintorial affinities. As occurs in Raja erinacea and R. eglanteria (Hamlett et al., 1998a), the gland of S. acuta expands their lateral borders before the arrival of the egg due,

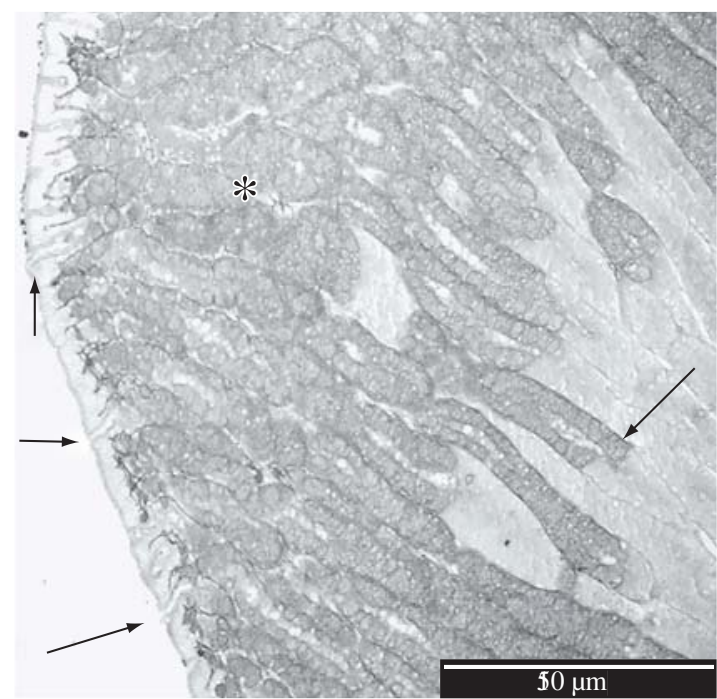

Figure 11. Low magnification of the terminal zone. Arrows indicate the opening of the glands, asterisk shows the mucous adenomers and arrowhead the beginning of the serous section. $\mathrm{AB}$ reaction. $\mathrm{Bar}=150 \mu \mathrm{m}$.

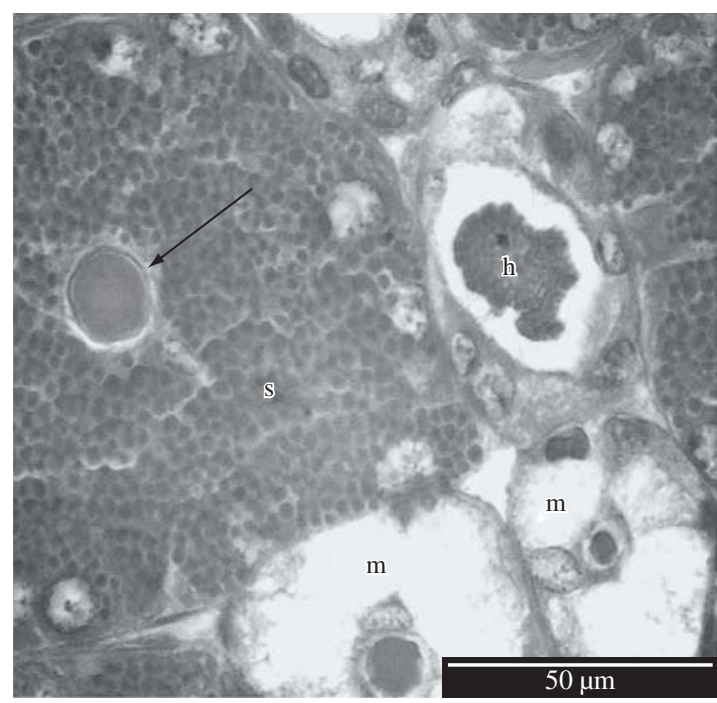

Figure 12. High magnification of adenomers from the "terminal" zone. s: serous adenomer, m: mucous adenomer, h: hair, arrow indicates the hair inside the adenomer with a hyalinized ring. Masson stain. $\mathrm{Bar}=50 \mu \mathrm{m}$. 
principally, to an increase of the length of tubular adenomers.

The oviduct is an unspecialized duct. From it, the most anterior region of the oviductal gland is the club zone. S. acuta shows here a strong reactivity to the Schiff reagent and the Alcian Blue dye, indicating the presence of acid mucins as occurs in S. canicula (Threadgold, 1957, Rusaouën, 1976; Feng and Knight, 1992), in $R$. eglanteria, R. erinacea (Hamlett et al., 1998a), in C. millii (Smith et al., 2004) and in the guitarfish (Rhinobatus granulosus: Prasad, 1945; R. lentiginosus: Hamlett et al., 1998b). The papillary zone depicts the same morphological characteristics as the other studied oviparous species, but its mucins pattern distribution is different from other Rajidae and similar to $S$. canicula (Feng and Knight, 1992), who interpret them as sulphated glycosamins mucopolysaccharides. Both zones, club and papillary, secrete the third envelopes of the eggs. There is not evidence that the club's jelly was a nutritional function (Koob and Strauss, 1998) rather it may have a support function for the developing embryo (Hamlett et al., 1998b). On the other hand, the papillary's jelly was postulated as a lubricant between egg and case (Nalini, 1940) or, in the case of jelly produced by the last adenomers (intermediate zone), may be interpreted as a demarcation between egg and case (Knight et al., 1996). A more extended investigation about the nature of secretions for clarifying its functions is necessary. One possibility, viewing the immunology complexity of reproduction in other elasmobranchs (Paulesu et al., 2004), is that jellies may participate in the contribution of maternal immunoglobulins to the developing embryo as with the uteroplacental complex in Mustelus canis (Cateni et al., 2003), and even more if we bear in mind that passive immunity is important for oviparous species because they are born protected by the egg case but probably with their immune system not completely developed (Haines et al., 2005).

The baffle zone is completely negative for sugars. Their function is the production of the egg case (Hamlett et al., 1998a) and comprises the secretion of a protein polymer similar to a "liquid crystal" through the grooves and that join in the lumen of the gland (Knight et al., 1996). In S. acuta this region seems similar to other oviparous species (Hamlett et al., 1998a, Smith et al., 2004). One characteristic of these animals is the formation of hairs and tendrils in the egg case used for their fixation to different substrates. In $S$. acuta, as in $R$. eglanteria and C. millii (Hamlett et al., 1998a; Smith et al., 2004) the terminal zone is the place for their formation. This zone has different acini and the mucous ones secrete acid mucopolysaccharides while the serous ones produce the hairs. An interesting difference in our species is that in not one examined example have we found spermatozoa. The sperm storage is common in elasmobranchs and in most oviparous studies, species spermatozoa were found in the terminal or/and in the baffle zones (Knight et al., 1996; Hamlett et al., 2003, Smith et al., 2004). It is im- possible to determine if the absence of sperm in the genital tract of females is due to the sampling zone, or to the season, or to a specific characteristic, but there are other examples of no sperm storage in elasmobranchs (Tricas et al., 2002, Dasyatis sabina).

The most disembarked species of skates in Mar del Plata, the principal commercial harbor of Argentina, include S. bonapartii and S. acuta (Massa et al., 2004) and both of them coexist in all of their distribution area (De Queiroz, 1995; Mabragaña et al., 2002). In spite of the advertised danger of over-fishing, information about the biology of these species is scarce. Recently the bignose fanskate was classified by the Red Book as a "vulnerable" species (IUCN, 2004) and so we are at risk of losing a species without completely understanding it. For the successful management of this fishing resource, the knowledge of all biological parameters, and specially the specific reproductive characteristics, will be necessary.

\section{References}

BRACCINI, JM., CHIARAMONTE, EG., 2002. Biología de la raya Psammobatis extenta (Garman, 1913) (Batoidea, Rajidae). Rev. Chilena Hist. Nat., vol. 75, no. 1, p. 179-188.

CATENI, C., PAULESU, L., BIGLIARDI, E. and HAMLETT, WC., 2003. The interleukin I (Il-1) system in the uteroplacental complex of a cartilaginous fish, the smoothound shark Mustelus canis. Reprod. Biol. Endocrinol., vol. 1, p. 25, doi: 10.1186/1477-7827-1-25.

CEDROLA, PV., GONZÁLEZ, AM. and PETTOVELLO, AD., 2005. Bycatch of skates (Elasmobranchii: Arhynchobatidae, Rajidae) in the Patagonian red shrimp fishery. Fisheries Res., vol. 71, p. 141-150

CHIARAMONTE, GE., 1998. Shark fisheries in Argentina. Mar. Freshwater Res., vol. 49, no. 7, p. 601-609.

CHIARAMONTE, GE. and PETTOVELlO, AD., 2000. The biology of Mustelus schmitti in the southern Patagonia, Argentina. J. Fish Biol., vol. 57, no. 4, p. 930-942.

COUSSEAU, MB., 1986. Estudios biológicos sobre peces costeros con datos de dos campañas de investigación realizadas en 1981. IV. El gatuzo (Mustelus schimitti). Publicaciones Científicas Tecnológicas de la Comisión Técnica Mixta del Frente Marítimo, vol. 1, p. 60-65.

DE QUEIROZ, EL., 1995. Coocorrencia entre Sympterygia acuta Garman 1877 e Sympterygia bonapartei Müller and Henle, 1841 (Elasmobranchii, Rajiformes). Especies endemicas e simpatricas na plataforma continental do Rio Grande Do Sul, Brasil. Rev. Brasileira Biol. $=$ Braz. J. Biol., vol. 53, no. 2, p. 293-303.

DULVY, NK. and REYNOLDS, JD., 2002. Predicting extinction vulnerability in skates. Conservation Biol., vol. 16, no. 2 , p. $440-450$.

FENG, D. and KNIGHT, DP., 1992. Secretion and stabilization of the layers of the egg capsule of the dogfish Scyliorhynus canicula, Tissue and Cell, vol. 24, no. 5, p. 773-790.

HAINES, AN., FLAJNIK, MF., RUMFELT, LL. and WOURMS, JP., 2005. Immunoglobulins in the eggs of the nurse shark, Ginglymostoma cirratum. Dev. Comp. Immunol., vol. 29, p. $417-430$. 
HAMLETT, WC., KNIGHT, DP., PEREIRA, FTV., STEELE, J. AND SEVER, DM., 2005. Oviducal glands in chondrichthyans. In: JAMIESON, BGM (series ed.), Reproductive biology and phylogeny of Chondrichthyes, vol. 3, HAMLETT, WC (ed.). Reproductive biology and phylogeny of chondrichthyes. Sharks, Batoids and Chimaeras, Science Publishers Inc., Enfield, p. 301-335.

HAMLETT, WC., KNIGHT, DP., KOOB, TJ., JEZIOR, M., LUONG, T., ROZYCKI, T., BRUNETTE, N. and HYSELL, MK., 1998a. Survey of oviductal gland structure and function in elasmobranchs. J. Exp. Zool., vol. 282, no. 4-5, p. 399-420.

HAMLETT, WC., HYSELL, MK., GALVIN, J. and SPIELER, R., 1998b. Reproductive accommodations for gestation in the atlantic guitarfish Rhinobatos lentiginosus (Rhinobatidae). J. Elisha Mitchell Sci. Soc., vol. 114, no. 4, p. 199-208.

HAMLETT, WC. and KOOB, TJ., 1999. Female reproductive system. In HAMLETT, WC. (ed). Biology of Elasmobranchs Fishes, The Johns Hopkins University Press. Baltimore, p. 398-443.

HAMLETT, WC., FISHELSON, L., BARANES, A., HYSELL, CK. and SEVER, DM., 2002. Ultrastructural analysis of sperm storage and morphology of the oviducal gland in the Oman shark Iago omanensis (Triakidae). Mar. Freshwater Res., vol. 53, no. 2, p. 601-613.

HAMLETT, WC., GREVEN, H. and SCHINDLER, J., 2003. Sperm storage in the class Chondrichthyes and the class Osteichthyes. In LEGARKI, S., STENTHOURAKIS, R., and THESSALOU-LEGAKI, M. (Eds). The new panorama of animal evolution, Proc. $18^{\text {th }}$ Int. Congr. Zoology, Sofia-Moscow. Pensoft Publishers.

HOENIG, JM. and GRUBER, SH., 1990. Life history patterns in the elasmobranchs: implications for fisheries management. In PRATT, HL., GRUBER, SH. and TANUICHI, T. (Eds). Elasmobranchs as living resources: Advances in the Biology, Ecology, Systematics and the Status of the Fisheries. NOAA Technical Report NMFS., vol. 90, p. 427-441.

IUCN 2004. Red List of Threatened Species. <www.iucnredlist. org>. [Access: December 12, 2005].

KNIGHT, DP., FENG, D. and STEWART, M., 1996. Structure and function of the Selachian egg case. Biol. Rev., vol. 71, p. 81-111.

KOOB, TJ. and STRAUS, JW., 1998. On the role of egg jelly in Raja erinacea. Bull. Mt. Desert Island Biol. Lab., vol. 37, p. 117-119.

LÓPEZ CAZORLA, A., Contribución al conocimiento de la ictiofauna marina del área de Bahía Blanca, Facultad de Ciencias Naturales y Museo, (Tesis Doctoral) - Universidad Nacional de La Plata, 247p.

LUCIFORA, LO., MENNI, RC. and ESCALANTE, AH., 2000a. Madurez sexual, ciclo reproductivo, segregación sexual y movimientos estacionales del tiburón Carcharhinus brachyurus en el Atlántico Sudoccidental. Resúmenes XV Simposio Científico Tecnológico de la Comisión Técnica Mixta del Frente Marítimo, Mar del Plata, p. 25-26.

LUCIFORA, LO., VALERO, JL., BREMEC, CS. and LASTA, ML., 2000b. Feeding habits and prey selection by the skate Dipturus chilensis (Elasmobranchii, Rajidae) from the Southwestern Atlantic. J. Mar. Biol. Ass., vol. 80, no. 5, p. 953-954.

LUCIFORA, LO., MENNI, RC. and ESCALANTE, AH., 2002. Reproductive ecology and abundance of the sand tiger shark,
Carcharias taurus from the Southwestern Atlantic. ICES $J$. Marine Sci., vol. 59, no. 3, p. 553-561.

LUCIFORA, LO. and GARCÍA, VB., 2004. Gastropod predation on egg cases of skates (Chondrichthyes, Rajidae) in the Southwestern Atlantic: quantification and life history implications. Mar. Biol. (Berlin)., vol. 145, no. 5, p. 917-922.

MABRAGAÑA, E., LUCIFORA, L. and MASSA, AM., 2002. The reproductive ecology and abundance of Sympterygia bonapartii endemic to the southwest Atlantic. J. Fish Biol., vol. 60 , no. 4 , p. 951-967.

MASSA, AM., LUCIFORA, L. and HOZBOR, NM., 2003. Condríctios de la región costera bonaerense y uruguaya. In SÁNCHEZ, R. and BEZZI, S. (Eds.). El Mar Argentino y sus recursos pesqueros. Tomo 4. Biología y Evaluación del Estado de Explotación. Publicaciones Especiales, INIDEP, Mar del Plata, p. 85-99.

MASSA, A., HOZBOR, N. and COLONELlO, J., 2004. Situación actual y avances en el estudio de los peces cartilaginosos. Inf. Téc. INIDEP, vol. 57, 18 p.

MCEACHRAN, JD. and DUNN, KA., 1998 . Phylogenetic analysis of skates, a morphologically conservative clade of elasmobranchs (Chondrichthyes, Rajidae). Copeia, vol. 1998, no. 2, p. 271-290.

METTEN, H., 1939. Studies on the reproduction of the dogfish. Phil. Trans. Roy. Soc., London, Series B, vol. 230, no. 569, p. $217-238$.

NALINI, KP., 1940. Structure and function of the nidamental gland of Chyloscyllium grisseum.

(Müller and Henle). Proc. Indian Acad. Sci., Series B, vol. 12, p. $189-214$

ODDONE, MC. and VOOREN, CM., 2002. Egg-case and size at hatching of Sympterygia acuta in the South-Western Atlantic. J. Fish Biol., vol. 61, no. 3, p. 858-861.

PAULESU, L, ROMAGNOLI, R. and BIGLIARDI, E., 2005. Maternal-fetal immunotolerance: is the interleukin-1 a fundamental mediator in placental viviparity? Dev. Comp. Immunol., vol. 29, no. 5, p. 409-415.

PRASAD, RR., 1945. The structure, phylogenetic significance, and function of the nidamental glands of some elasmobranchs of the Madras coast. Proc. Nat. Inst. Sci. India, Series B, vol. 22, p. 282-303.

PRATT, HL., 1993. The storage of spermatozoa in the oviductal glands of western North Atlantic sharks. Environ. Biol. Fish., vol. 38 , no. $1-3$, p. 139-149.

RUSAOUËN, M., 1976. The dogfish shell gland, a histochemical study. J. Exp. Mar. Biol. Ecol., vol. 23, no. 3, p. 267-283.

SMITH, RM., WALKER, TI. and HAMLETT, WC., 2004 Microscopic organisation of the oviducal gland of the holocephalan elephant fish, Callorhynchus millii. Mar. Freshwater Res., vol. 55, no. 2, p. 155-164.

THREADGOLD, LT., 1957. A histochemical study of the shell gland of Scyliorhinus canicula. J. Histochem. Cytochem., vol. 5, no. 2, p. 159-166.

TRICAS, TC., MARUSKA, KP. and RASMUSSEN, LEL. 2000. Annual cycles of steroid hormone production, gonad development and reproductive behavior in the Atlantic stingray. Gen. Comp. Endocrinol., vol. 118, no. 2, p. 209-225. 